
death in presence of myocardial infarction: the Framingham study//

\author{
Ralph BL'Agostino, Albert Eelanger, William B Kannel, John M Cruickshank
}

\section{Abstract}

Objective-To examine the hypothesis that a J curve relation between blood pressure and death from coronary heart disease is confined to high risk subjects with myocardial infarction.

Design-Cohort longitudinal epidemiological study with biennial examinations since 1950 .

Setting-Framingham, Massachusetts, USA.

Subjects-5209 subjects in the Framingham study cohort followed up by a person examination approach.

Main outcome measures-Coronary heart disease deaths and non-cardiovascular disease deaths in men and women with or without myocardial infarction relative to blood pressure.

Results-Among subjects without myocardial infarction non-cardiovascular disease deaths were twice to three times as common as coronary heart disease deaths. Furthermore, there was no significant relation between non-cardiovascular disease death and diastolic or systolic blood pressure. Also coronary heart disease deaths were linearly related to diastolic and systolic blood pressures. Among high risk patients (that is, people with myocardial infarction but free of congestive heart failure) death from coronary heart disease was more common than non-cardiovascular disease death. There was a significant $U$ shaped relation between coronary heart disease death and diastolic blood pressure. Although there was an apparent $U$ shaped relation between coronary heart disease death and systolic blood pressure, it did not attain statistical significance when controlling for age and change in systolic blood pressure from the pre-myocardial infarction level. None of the above conclusions changed when adjustments were made for risk factors such as serum cholesterol concentration, antihypertensive treatment, and left ventricular function. The $U$ shaped relation between diastolic blood pressure and high risk subjects existed for both those given antihypertensive treatment and those not.

Conclusions-These data sugest that an age and sex independent $U$ curve relation exists for diastolic blood pressure and coronary heart disease deaths in patients with myocardial infarction but not for low risk subjects without myocardial infarction. The relation seems to be independent of left ventricular function and antihypertensive treatment.

\section{Introduction}

Traditional views hold that the lower the blood pressure the lower will be the total mortality and the fewer the deaths from myocardial infarction and stroke. These views, however, tend to stem from databases composed mainly of people at low risk of coronary heart disease. ${ }^{12}$ More heterogeneous populations, ${ }^{34}$ including our own, ${ }^{5}$ have suggested that low diastolic blood pressure may be associated with an excess of cardiac events. Cruickshank et al suggested that a J curve relation between diastolic blood pressure and death from myocardial infarction was confined to hypertensive patients with coronary heart disease, ${ }^{6}$ whereas others claimed that such a relation existed in those both with and without coronary heart disease. ${ }^{7-10}$ We have therefore re-examined our data using 34 years of follow up to test prospectively the hypothesis that the J curve relation between blood pressure and death from coronary heart disease is confined to high risk subjects - that is, people with myocardial infarction.

\section{Patients and methods} FRAMINGHAM STUDY

The Framingham study was initiated in 1948 on a cohort of 5209 subjects ( 2336 men, 2873 women) aged 30 to 62 . They have been followed up by means of biennial examinations in order to measure cardiovascular risk factors and to relate these to the development of cardiovascular diseases, to detect changes in rates of cardiovascular disease morbidity and mortality over time, and to evaluate all cause mortality. ${ }^{112}$ Details of clinical criteria and laboratory methods have been reported. ${ }^{12}{ }^{13}$ Coronary heart disease deaths include deaths from myocardial infarction and sudden and non-sudden deaths from coronary heart disease. Sudden death was defined as death in a person who had apparently been well and died within 60 minutes of onset of symptoms in the absence of other apparent causes. Cardiovascular disease deaths include coronary heart disease deaths, deaths from stroke, and deaths from other cardiovascular causes. ${ }^{13}$

\section{STATISTICAL ANALYSIS}

A person examination approach was employed for the statistical analysis. This has been explained elsewhere together with its relation to other statistical procedures. ${ }^{14}$ is At each biennial examination all subjects aged 45-84 and free of congestive heart failure were classified into one of two groups as either having a history of myocardial infarction or not having a history of myocardial infarction. Those free of congestive heart failure were selected so as to remove from the analyses anyone obviously sick. Subjects were also classified according to their diastolic and systolic blood pressures. Observations over the next two years recorded whether the subject died and whether the death was due to coronary heart disease, cardiovascular disease, or other causes (non-cardiovascular disease deaths). This was repeated for each examination up to examination 17 and the data pooled. From this biennial age adjusted rates were computed along with the standard errors (SE) of the age adjusted rates.

Logistic regression with the pooled person examination data ${ }^{14}$ is was employed to test the relation of event requests for reprints to: Dr D'Agostino.

BMF 1991;303:385-9 
rates - for example, coronary heart disease death rates - to blood pressure levels after adjusting for age and, as appropriate, other cardiovascular risk factors, such as change in blood pressure from before myocardial infarction, diabetes, smoking, and cholesterol concentration. This logistic analysis is related to the Cox proportional hazard regression analysis, employing the risk factors as time dependent covariates. ${ }^{15}$ To test the non-linearity of the relation both linear and quadratic terms for blood pressure were entered into the regression. The J shape or U shape was said to exist if both terms were statistically significant (taken as $p<0.05$ ) and the coefficients had appropriate signs to produce a $\mathrm{J}$ or $\mathrm{U}$ shape. For confirmation of results other devices were also employed - namely, analyses using dummy variables for blood pressure categories (diastolic blood pressure $<70,70-74,75-79, \ldots \mathrm{mm} \mathrm{Hg}$ ) and piecewise linear segments. The results of these agreed with the analysis employing the linear and quadratic terms.

\section{Results}

DIASTOLIC BLOOD PRESSURE AND DEATH RATES

Death rates from coronary heart disease and noncardiovascular causes in low risk subjects (that is, those without myocardial infarction) are shown in table I. Non-cardiovascular disease deaths were twice to three times as common as coronary heart disease deaths. Coronary heart disease deaths tended to be less common the lower the diastolic blood pressure, whereas non-cardiovascular disease deaths tended to decrease with increasing diastolic blood pressures up to $80 \mathrm{~mm} \mathrm{Hg}$ and then rise. For coronary heart disease

TABLE I-Coronary heart disease deaths and non-cardiovascular disease deaths relative to diastolic blood pressure in men and women with or without previous myocardial infarction

\begin{tabular}{|c|c|c|c|c|c|c|c|c|}
\hline \multirow[b]{2}{*}{$\begin{array}{l}\text { Previous } \\
\text { myocardial } \\
\text { infarction }\end{array}$} & \multirow[b]{2}{*}{$\begin{array}{l}\text { Diastolic } \\
\text { blood } \\
\text { pressure } \\
(\mathrm{mm} \mathrm{Hg})\end{array}$} & \multirow[b]{2}{*}{$\begin{array}{c}\text { No of } \\
\text { person } \\
\text { examinations }\end{array}$} & \multicolumn{3}{|c|}{ Coronary heart disease death } & \multicolumn{3}{|c|}{ Non-cardiovascular disease death } \\
\hline & & & $\begin{array}{l}\text { No of } \\
\text { events }\end{array}$ & $\begin{array}{l}\text { Age adjusted } \\
\text { biennial } \\
\text { death } \\
\text { rate/1000 } \\
\text { population }\end{array}$ & SE & $\begin{array}{l}\text { No of } \\
\text { events }\end{array}$ & $\begin{array}{l}\text { Age adjusted } \\
\text { biennial } \\
\text { death } \\
\text { rate/1000 } \\
\text { population }\end{array}$ & SE \\
\hline \multirow{7}{*}{ No } & $<<70$ & 5593 & 43 & 6.0 & 0.9 & 150 & $21 \cdot 4$ & 1.8 \\
\hline & $70-74$ & 9006 & 61 & $6 \cdot 3$ & 0.8 & 185 & $19 \cdot 0$ & 1.4 \\
\hline & $75-79$ & 5770 & 30 & $5 \cdot 2$ & 0.9 & 106 & $18 \cdot 3$ & 1.7 \\
\hline & $80-84$ & 12787 & 78 & $6 \cdot 4$ & 0.7 & 190 & $15 \cdot 6$ & $1 \cdot 1$ \\
\hline & $85-89$ & 5951 & 43 & $8 \cdot 3$ & $1 \cdot 3$ & 90 & $16 \cdot 4$ & 1.7 \\
\hline & $90-94$ & 7164 & 70 & $10 \cdot 0$ & $1 \cdot 2$ & 135 & 19.9 & 1.7 \\
\hline & $\geqslant 95$ & 7872 & 88 & 13.9 & 1.5 & 136 & $20 \cdot 3$ & 1.8 \\
\hline \multirow{7}{*}{ Yes } & $<>70$ & 307 & 28 & $113 \cdot 6$ & $31 \cdot 7$ & 15 & $26 \cdot 1$ & $7 \cdot 8$ \\
\hline & 70-74 & 432 & 28 & $64 \cdot 4$ & $14 \cdot 7$ & 15 & $27 \cdot 1$ & 8.9 \\
\hline & $75-79$ & 242 & 12 & $42 \cdot 4$ & $15 \cdot 0$ & 9 & $46 \cdot 7$ & $18 \cdot 5$ \\
\hline & $80-84$ & 492 & 31 & $59 \cdot 5$ & 11.9 & 21 & $30 \cdot 0$ & $7 \cdot 7$ \\
\hline & $85-89$ & 245 & 15 & $57 \cdot 0$ & 15.0 & 4 & 10.5 & $5 \cdot 1$ \\
\hline & $90-94$ & 274 & 18 & 53.9 & 13.6 & 18 & 45.9 & $10 \cdot 3$ \\
\hline & $\geqslant 95$ & 351 & 32 & 93.0 & $16 \cdot 6$ & 7 & $16 \cdot 6$ & $6 \cdot 1$ \\
\hline
\end{tabular}

TABLE II-Coronary heart disease deaths and non-cardiovascular disease deaths relative to systolic blood pressure in men and women with and without previous myocardial infarction

\begin{tabular}{|c|c|c|c|c|c|c|c|c|}
\hline \multirow[b]{2}{*}{$\begin{array}{l}\text { Previous } \\
\text { myocardial } \\
\text { infarction }\end{array}$} & \multirow[b]{2}{*}{$\begin{array}{l}\text { Systolic } \\
\text { blood } \\
\text { pressure } \\
(\mathrm{mm} \mathrm{Hg})\end{array}$} & \multirow[b]{2}{*}{$\begin{array}{c}\text { No of } \\
\text { person } \\
\text { examinations }\end{array}$} & \multicolumn{3}{|c|}{ Coronary heart disease death } & \multicolumn{3}{|c|}{ Non-cardiovascular disease death } \\
\hline & & & $\begin{array}{c}\text { No of } \\
\text { events }\end{array}$ & $\begin{array}{l}\text { Age adjusted } \\
\text { biennial } \\
\text { death } \\
\text { rate } / 1000 \\
\text { population }\end{array}$ & SE & $\begin{array}{l}\text { No of } \\
\text { events }\end{array}$ & $\begin{array}{l}\text { Age adjusted } \\
\text { biennial } \\
\text { death } \\
\text { rate } / 1000 \\
\text { population }\end{array}$ & SE \\
\hline \multirow{7}{*}{ No } & $\mid<120$ & 9360 & 24 & 3.4 & 0.7 & 155 & $23 \cdot 2$ & 1.9 \\
\hline & $120-129$ & 9182 & 40 & $5 \cdot 4$ & 0.9 & 125 & $16 \cdot 2$ & 1.5 \\
\hline & $130-139$ & 10527 & 65 & $6 \cdot 4$ & 0.8 & 183 & $18 \cdot 6$ & 1.4 \\
\hline & $\left\{\begin{array}{l}140-149 \\
\text { a }\end{array}\right.$ & 8175 & 68 & $8 \cdot 0$ & 1.0 & 166 & $19 \cdot 5$ & 1.5 \\
\hline & $150-159$ & 6128 & 63 & $9 \cdot 4$ & 1.2 & 124 & $18 \cdot 7$ & 1.7 \\
\hline & $160-169$ & 4276 & 46 & $9 \cdot 4$ & 1.4 & 87 & $18 \cdot 5$ & $2 \cdot 0$ \\
\hline & $\geqslant 170$ & 6495 & 107 & $13 \cdot 8$ & 1.4 & 152 & $19 \cdot 8$ & 1.7 \\
\hline \multirow{7}{*}{ Yes } & $<<120$ & 304 & 21 & $74 \cdot 7$ & $16 \cdot 0$ & 12 & $41 \cdot 2$ & $12 \cdot 1$ \\
\hline & $120-129$ & 338 & 20 & $57 \cdot 8$ & 13.0 & 7 & $20 \cdot 3$ & $7 \cdot 7$ \\
\hline & $130-139$ & 428 & 29 & $60 \cdot 8$ & 12.5 & 13 & $21 \cdot 5$ & $6 \cdot 0$ \\
\hline & $140-149$ & 412 & 29 & $66 \cdot 3$ & $15 \cdot 1$ & 20 & $26 \cdot 6$ & $6 \cdot 3$ \\
\hline & $150-159$ & 293 & 18 & $59 \cdot 2$ & $17 \cdot 7$ & 14 & $30 \cdot 1$ & $8 \cdot 3$ \\
\hline & $160-169$ & 237 & 14 & 77.9 & $28 \cdot 6$ & 11 & $23 \cdot 7$ & $8 \cdot 0$ \\
\hline & $\geqslant 170$ & 331 & 33 & $83 \cdot 1$ & $19 \cdot 4$ & 12 & $19 \cdot 2$ & $6 \cdot 3$ \\
\hline
\end{tabular}

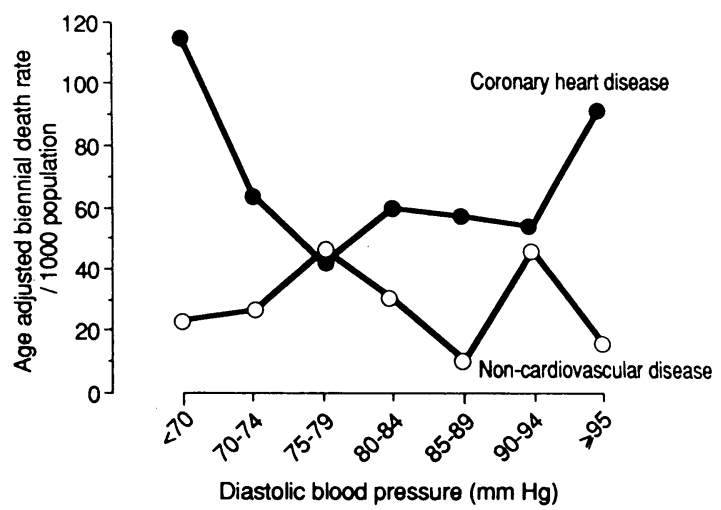

FIG 1-Coronary heart disease deaths and non-cardiovascular disease deaths relative to diastolic blood pressure in men and women with previous myocardial infarction

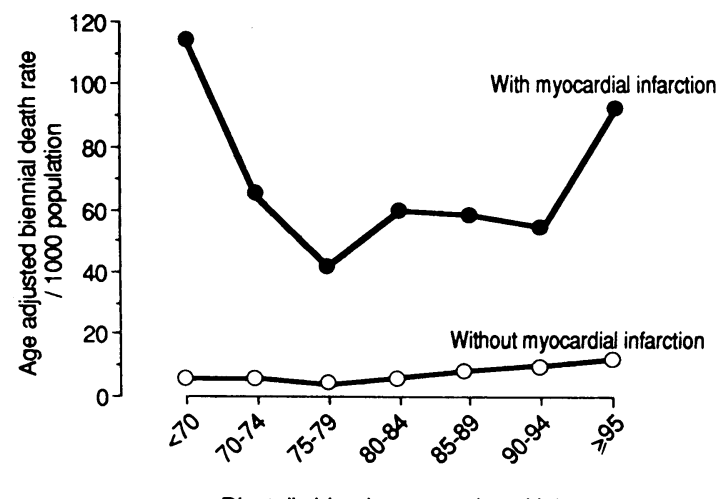

Diastolic blood pressure $(\mathrm{mm} \mathrm{Hg})$

FIG 2-Coronary heart disease deaths relative to diastolic blood pressure in men and women with or without previous myocardial infarction

deaths there was a positive, monotonically increasing continuous relation with diastolic blood pressure $(95 \%$ confidence interval for linear term 0.0176 to 0.0324 , $\chi^{2}=44 \cdot 29, \mathrm{p}<0 \cdot 0001$; quadratic term NS).

In high risk patients (that is, people with myocardial infarction) death from coronary heart disease was more common than non-cardiovascular disease death (table I; fig 1). There was no systematic relation between non-cardiovascular disease deaths and diastolic blood pressure. Rates of coronary heart disease deaths, however, tended to decrease as a function of diastolic blood pressure up to values in the high $70 \mathrm{~s}$ ( $\mathrm{mm} \mathrm{Hg}$; phase V) and then rose significantly (95\% confidence interval for linear term -0.1991 to -0.0333 , $\chi^{2}=7 \cdot 54, p=0.006 ; 95 \%$ confidence interval for quadratic term 0.000319 to $0.001255, \chi^{2}=10.87, p=0.001$ ) after adjusting for age and change from pre-myocardial infarction diastolic blood pressure. The contrast between the relation of diastolic blood pressure and coronary heart disease deaths in high risk and low risk patients is shown in figure 2. Among the high risk patients the relation was more $U$ shaped than $\mathrm{J}$ shaped.

\section{SYSTOLIC BLOOD PRESSURE AND DEATH RATES}

Rates of non-cardiovascular disease deaths bore no significant relation to systolic blood pressure in either low risk (no myocardial infarction) or high risk (history of myocardial infarction) groups (table II), though there seemed to be an excess with systolic blood pressures below $120 \mathrm{~mm} \mathrm{Hg}$. In contrast, coronary heart disease deaths were related to systolic blood pressure in the low risk group (table II; fig 3). Among these subjects the overall coronary heart disease death rate was low and bore a positive linear and continuous relation with systolic blood pressure $(95 \%$ confidence interval for linear term, $0 \cdot 0107$ to $0 \cdot 0177, \chi^{2}=62 \cdot 16$, $\mathrm{p}<0.0001$; quadratic term NS). In those with myo- 


\begin{tabular}{|c|c|c|c|c|c|c|c|c|c|}
\hline $\begin{array}{l}\text { Previous } \\
\text { myocardial } \\
\text { infarction }\end{array}$ & $\begin{array}{l}\text { Diastolic } \\
\text { blood } \\
\text { pressure } \\
(\mathrm{mm} \mathrm{Hg}) \\
\end{array}$ & $\begin{array}{c}\text { Serum } \\
\text { cholesterol } \\
(\mathrm{mmol} / \mathrm{l})\end{array}$ & $\begin{array}{l}\% \text { With } \\
\text { diabetes }\end{array}$ & $\begin{array}{c}\% \text { Having } \\
\text { antihypertensive } \\
\text { treatment }\end{array}$ & $\begin{array}{l}\text { \% Smoking } \\
\text { cigarettes }\end{array}$ & $\begin{array}{l}\text { Metropolitan } \\
\text { relative } \\
\text { weight } \\
(\%)^{\star}\end{array}$ & $\begin{array}{l}\text { Packed cell } \\
\text { volume }\end{array}$ & $\begin{array}{l}\% \text { With } \\
\text { heart } \\
\text { enlargement in } \\
\text { radiographs }\end{array}$ & $\begin{array}{c}\% \text { With left } \\
\text { ventricular } \\
\text { hypertrophy } \\
\text { diagnosed from } \\
\text { electrocardiograms }\end{array}$ \\
\hline \multirow{7}{*}{ No } & $<<70$ & 5.98 & $6 \cdot 4$ & $7 \cdot 6$ & $43 \cdot 5$ & $113 \cdot 2$ & $0 \cdot 437$ & $9 \cdot 9$ & $2 \cdot 3$ \\
\hline & $70-74$ & $6 \cdot 11$ & $5 \cdot 7$ & $9 \cdot 6$ & $39 \cdot 3$ & $116 \cdot 3$ & 0.443 & $9 \cdot 9$ & $2 \cdot 1$ \\
\hline & $75-79$ & $6 \cdot 13$ & $6 \cdot 4$ & $11 \cdot 6$ & $37 \cdot 0$ & $118 \cdot 6$ & 0.448 & $10 \cdot 3$ & $2 \cdot 3$ \\
\hline & $80-84$ & $6 \cdot 19$ & $6 \cdot 1$ & $13 \cdot 3$ & $34 \cdot 6$ & $121 \cdot 4$ & 0.450 & $10 \cdot 2$ & $2 \cdot 5$ \\
\hline & $85-89$ & $6 \cdot 30$ & $6 \cdot 3$ & $16 \cdot 1$ & $33 \cdot 6$ & $124 \cdot 0$ & 0.455 & $11 \cdot 1$ & $4 \cdot 1$ \\
\hline & $90-94$ & $6 \cdot 33$ & $6 \cdot 4$ & $18 \cdot 8$ & $32 \cdot 0$ & $125 \cdot 4$ & 0.455 & $12 \cdot 1$ & $4 \cdot 7$ \\
\hline & $\geqslant 95$ & $6 \cdot 42$ & $7 \cdot 1$ & $22 \cdot 8$ & $33 \cdot 3$ & $131 \cdot 0$ & 0.461 & $13 \cdot 4$ & $11 \cdot 0$ \\
\hline \multirow{7}{*}{ Yes } & $<<70$ & $5 \cdot 85$ & $16 \cdot 3$ & $10 \cdot 5$ & $45 \cdot 8$ & $114 \cdot 6$ & 0.454 & $16 \cdot 3$ & $7 \cdot 2$ \\
\hline & $70-74$ & $5 \cdot 91$ & $14 \cdot 8$ & 13.7 & 43.8 & 116.0 & 0.463 & $15 \cdot 3$ & $8 \cdot 1$ \\
\hline & $75-79$ & $5 \cdot 83$ & $15 \cdot 5$ & $13 \cdot 7$ & $50 \cdot 5$ & $119 \cdot 2$ & 0.464 & $15 \cdot 6$ & 3.5 \\
\hline & $\{80-84$ & $6 \cdot 17$ & $15 \cdot 5$ & $18 \cdot 0$ & $41 \cdot 0$ & $121 \cdot 2$ & 0.461 & $13 \cdot 2$ & $6 \cdot 2$ \\
\hline & $85-89$ & $6 \cdot 37$ & $11 \cdot 8$ & $21 \cdot 8$ & 43.9 & $123 \cdot 3$ & 0.472 & $11 \cdot 5$ & $4 \cdot 6$ \\
\hline & $90-94$ & 6.53 & $7 \cdot 7$ & $22 \cdot 0$ & 51.7 & 122.8 & 0.467 & $14 \cdot 3$ & $8 \cdot 7$ \\
\hline & $\geqslant 95$ & $6 \cdot 44$ & $9 \cdot 4$ & $20 \cdot 2$ & $46 \cdot 6$ & 126.9 & 0.476 & $13 \cdot 1$ & $17 \cdot 9$ \\
\hline
\end{tabular}

^From Metropolitan Life Insurance Company tables.

TABLE IV - Relation between systolic blood pressure and cardiovascular risk factors. Entries are age adjusted means

\begin{tabular}{|c|c|c|c|c|c|c|c|c|c|}
\hline $\begin{array}{l}\text { Previous } \\
\text { myocardial } \\
\text { infarction }\end{array}$ & $\begin{array}{l}\text { Systolic } \\
\text { blood } \\
\text { pressure } \\
(\mathrm{mm} \mathrm{Hg}) \\
\end{array}$ & $\begin{array}{c}\begin{array}{c}\text { Serum } \\
\text { cholesterol } \\
(\mathrm{mmol} / \mathrm{l})\end{array} \\
\end{array}$ & $\begin{array}{c}\% \text { With } \\
\text { diabetes }\end{array}$ & $\begin{array}{c}\text { \% Having } \\
\text { antihypertensive } \\
\text { treatment }\end{array}$ & $\begin{array}{c}\text { \% Smoking } \\
\text { cigarettes }\end{array}$ & $\begin{array}{l}\text { Metropolitan } \\
\text { relative } \\
\text { weight } \\
(\%)^{\star}\end{array}$ & $\begin{array}{c}\text { Packed cell } \\
\text { volume }\end{array}$ & $\begin{array}{l}\% \text { With } \\
\text { heart } \\
\text { enlargement in } \\
\text { radiographs }\end{array}$ & $\begin{array}{c}\% \text { With left } \\
\text { ventricular } \\
\text { hypertrophy } \\
\text { diagnosed from } \\
\text { electrocardiograms }\end{array}$ \\
\hline No & $\left\{\begin{array}{l}>120 \\
120-129 \\
130-139 \\
140-149 \\
150-159 \\
160-169 \\
\geqslant 170\end{array}\right.$ & $\begin{array}{l}6 \cdot 02 \\
6 \cdot 09 \\
6 \cdot 16 \\
6 \cdot 24 \\
6 \cdot 35 \\
6 \cdot 34 \\
6 \cdot 48\end{array}$ & $\begin{array}{l}4 \cdot 0 \\
4 \cdot 9 \\
5 \cdot 9 \\
6 \cdot 1 \\
7 \cdot 0 \\
9 \cdot 0 \\
9 \cdot 9\end{array}$ & $\begin{array}{r}6 \cdot 5 \\
8 \cdot 9 \\
11 \cdot 4 \\
15 \cdot 2 \\
18 \cdot 0 \\
22 \cdot 5 \\
27 \cdot 7\end{array}$ & $\begin{array}{l}41 \cdot 5 \\
36 \cdot 4 \\
35 \cdot 8 \\
35 \cdot 1 \\
34 \cdot 3 \\
32 \cdot 5 \\
32 \cdot 5\end{array}$ & $\begin{array}{l}113 \cdot 6 \\
118 \cdot 3 \\
121 \cdot 2 \\
123 \cdot 5 \\
124 \cdot 8 \\
126 \cdot 4 \\
129 \cdot 8\end{array}$ & $\begin{array}{l}0 \cdot 444 \\
0 \cdot 447 \\
0 \cdot 451 \\
0 \cdot 453 \\
0 \cdot 452 \\
0 \cdot 453 \\
0 \cdot 451\end{array}$ & $\begin{array}{r}8 \cdot 1 \\
9 \cdot 2 \\
9 \cdot 7 \\
11 \cdot 3 \\
12 \cdot 1 \\
13 \cdot 0 \\
16 \cdot 6\end{array}$ & $\begin{array}{r}1 \cdot 2 \\
1 \cdot 3 \\
2 \cdot 2 \\
3 \cdot 1 \\
4 \cdot 8 \\
6 \cdot 5 \\
14 \cdot 2\end{array}$ \\
\hline Yes & $\left\{\begin{array}{l}<120 \\
120-129 \\
130-139 \\
140-149 \\
150-159 \\
160-169 \\
\geqslant 170\end{array}\right.$ & $\begin{array}{l}6 \cdot 02 \\
6 \cdot 02 \\
6 \cdot 25 \\
6 \cdot 16 \\
6 \cdot 28 \\
6 \cdot 19 \\
6 \cdot 30\end{array}$ & $\begin{array}{l}11 \cdot 6 \\
13 \cdot 1 \\
14 \cdot 7 \\
12 \cdot 5 \\
14 \cdot 2 \\
17 \cdot 0 \\
12 \cdot 0\end{array}$ & $\begin{array}{l}11 \cdot 4 \\
12 \cdot 4 \\
13 \cdot 0 \\
22 \cdot 4 \\
19 \cdot 4 \\
27 \cdot 2 \\
24 \cdot 0\end{array}$ & $\begin{array}{l}51 \cdot 9 \\
48 \cdot 7 \\
39 \cdot 4 \\
44 \cdot 9 \\
46 \cdot 7 \\
45 \cdot 8 \\
39 \cdot 7\end{array}$ & $\begin{array}{l}116 \cdot 7 \\
118 \cdot 9 \\
119 \cdot 9 \\
120 \cdot 9 \\
125 \cdot 9 \\
121.5 \\
127 \cdot 2\end{array}$ & $\begin{array}{l}0 \cdot 469 \\
0 \cdot 464 \\
0 \cdot 465 \\
0 \cdot 469 \\
0 \cdot 464 \\
0 \cdot 462 \\
0 \cdot 462\end{array}$ & $\begin{array}{l}17 \cdot 4 \\
13 \cdot 1 \\
14 \cdot 2 \\
10 \cdot 8 \\
11 \cdot 5 \\
15 \cdot 0 \\
21 \cdot 0\end{array}$ & $\begin{array}{r}3 \cdot 2 \\
4 \cdot 0 \\
6 \cdot 7 \\
7 \cdot 5 \\
6 \cdot 4 \\
10 \cdot 0 \\
25 \cdot 4\end{array}$ \\
\hline
\end{tabular}

$\star^{\star}$ From Metropolitan Life Insurance Company tables.

TABLE V-Coronary heart disease deaths relative to diastolic blood pressure in men and women with previous myocardial infarction by antihypertensive treatment

\begin{tabular}{|c|c|c|c|c|c|}
\hline \multirow[b]{2}{*}{$\begin{array}{l}\text { Antihypertensive } \\
\text { treatment }\end{array}$} & \multirow[b]{2}{*}{$\begin{array}{c}\text { Diastolic } \\
\text { blood } \\
\text { pressure } \\
(\mathrm{mm} \mathrm{Hg})\end{array}$} & \multirow[b]{2}{*}{$\begin{array}{l}\text { No of person } \\
\text { examinations }\end{array}$} & \multicolumn{3}{|c|}{ Coronary heart disease death } \\
\hline & & & No of events & $\begin{array}{c}\text { Age adjusted } \\
\text { biennial death } \\
\text { rate/1000 population }\end{array}$ & SE \\
\hline \multirow{7}{*}{ No } & $\{<70$ & 248 & 21 & $108 \cdot 4$ & $32 \cdot 0$ \\
\hline & $70-74$ & 345 & 22 & $66 \cdot 1$ & $16 \cdot 0$ \\
\hline & $75-79$ & 195 & 10 & $47 \cdot 5$ & 16.5 \\
\hline & $\{80-84$ & 374 & 21 & $54 \cdot 4$ & $12 \cdot 7$ \\
\hline & $85-89$ & 182 & 8 & $42 \cdot 2$ & $15 \cdot 1$ \\
\hline & $90-94$ & 202 & 13 & $60 \cdot 6$ & 16.6 \\
\hline & $\geqslant 95$ & 268 & 25 & $91 \cdot 2$ & $18 \cdot 3$ \\
\hline \multirow{7}{*}{ Yes } & $\mid<70$ & 59 & 7 & $86 \cdot 4$ & $41 \cdot 7$ \\
\hline & $70-74$ & 87 & 6 & $28 \cdot 4$ & $11 \cdot 1$ \\
\hline & $75-79$ & 47 & 2 & $26 \cdot 2$ & $17 \cdot 5$ \\
\hline & $80-84$ & 118 & 10 & $74 \cdot 2$ & $25 \cdot 5$ \\
\hline & $85-89$ & 63 & 7 & 94.9 & $35 \cdot 2$ \\
\hline & $90-94$ & 72 & 5 & $35 \cdot 5$ & $15 \cdot 6$ \\
\hline & $\geqslant 95$ & 83 & 7 & $104 \cdot 2$ & $41 \cdot 5$ \\
\hline
\end{tabular}

cardial infarction the overall coronary heart disease death rate was high and there was an apparent $\mathrm{U}$ shaped relation. This relation, however, was not significant when controlling for age and change in systolic blood pressure from the pre-myocardial infarction level.

RISK FACTOR AND BLOOD PRESSURE INTERACTION AND CORONARY HEART DISEASE DEATHS

The relations between diastolic and systolic blood pressures and the risk factors serum cholesterol concentration, prevalence of diabetes, prevalence of antihypertensive treatment, prevalence of smokers and numbers of cigarettes smoked, relative weight, packed cell volume, $x$ ray evidence of an enlarged heart, and impaired left ventricular function seen in the electrocardiogram in high risk and low risk groups are shown in tables III and IV. Serum cholesterol concentration, prevalence of antihypertensive treatment, relative weight, and packed cell volume bore a positive relation with blood pressure in both low risk and high risk groups. A negative relation was present for the prevalence of smokers and numbers of cigarettes smoked and pertained to both high risk and low risk groups. The $U$ shaped relation between coronary heart disease deaths and diastolic blood pressure was significant (95\% confidence interval for linear term -0.2019 to $-0.0259, \chi^{2}=6.44, p=0.011 ; 95 \%$ confidence interval for quadratic term 0.000282 to $0.001266, \chi^{2}=9 \cdot 47$, $\mathrm{p}=0.002$ ) after adjusting for age, change in diastolic blood pressure from before the myocardial infarction, and all the above risk factors for the subjects with myocardial infarction. The U shape was not significant for systolic blood pressure.

\section{ANTIHYPERTENSIVE TREATMENT $V$ NO TREATMENT}

The relation between diastolic blood pressure and coronary heart disease deaths in treated and nontreated high risk groups is shown in table $\mathrm{V}$. The $\mathrm{U}$

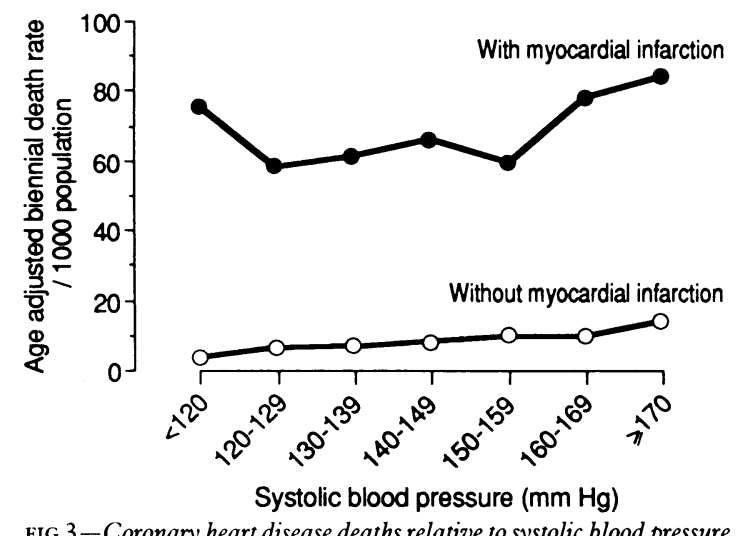

FIG 3-Coronary heart disease deaths relative to systolic blood pressure in men and women with or without previous myocardial infarction 
curve relation between diastolic blood pressure and coronary heart disease death seemed to be independent of treatment. For both groups the linear and quadratic terms were significant in the logistic regressions containing the full set of risk factors listed above.

\section{Discussion}

This breakdown of the Framingham database confirms that lower diastolic blood pressures are associated with fewer coronary heart disease deathsbut only for low risk subjects (that is, people without myocardial infarction). Similar results for coronary heart disease are well known and reported elsewhere. ${ }^{16}$ Non-cardiovascular disease deaths seemed not to be related to blood pressure in the low risk group.

Both high risk patients (those with myocardial infarction but not congestive heart failure) and low risk patients suffered non-cardiovascular disease deaths in a fashion unrelated to blood pressure. Coronary heart disease deaths, however, showed a significant tendency to form a $U$ shaped relation with diastolic blood pressure in the high risk group. This phenomenon could not be explained by odd distributions of the various coronary risk factors, such as cholesterol concentration, diabetes, smoking, obesity, treatment of hypertension, heart enlargement, and impaired left ventricular function. We have thus confirmed the observation ${ }^{6}$ that the J curve or U curve relation with diastolic blood pressure and coronary heart disease death, independent of age and sex, is specific to a high risk group. Others have emphasised a J shape. ${ }^{6}$ Our data seem to be better described as $U$ shaped. The relation of low diastolic blood pressure to high rates of coronary heart disease mortality is confirmed.

As regards left ventricular hypertrophy as diagnosed from the electrocardiogram we looked at patients with impaired left ventricular function and no myocardial infarction, patients with myocardial infarction and no impaired left ventricular function, and a group of high risk patients with both conditions. Although there were no statistically significant findings, the $U$ point in the first two groups was in the high $70 \mathrm{~s}(\mathrm{~mm} \mathrm{Hg})$ of diastolic pressure (as for cases with myocardial infarction) but in the combined impaired left ventricular function and myocardial infarction group the $U$ point was moved to the right - to the mid to high $80 \mathrm{~s}(\mathrm{~mm} \mathrm{Hg})$. This observation may warrant further investigation.

It has been suggested that the $\mathrm{J}$ curve or $\mathrm{U}$ curve relation between diastolic blood pressure and death from myocardial infarction is spurious and purely a reflection of either ill health, poor left ventricular function, ${ }^{21718}$ or overtreatment. ${ }^{2}$ To allow for this we analysed only patients without congestive heart failure and included in our analysis the change in diastolic blood pressure from the pre-myocardial infarction value. We found no evidence in the high risk group for poor left ventricular function being responsible, there being no increased frequency of cardiomegaly or increased heart rate in the groups immediately below the diastolic $U$ point or anywhere below the systolic $U$ point.

Staessen et al used low weight and haemoglobin concentration as evidence of ill health in elderly hypertensive patients with low diastolic blood pressure and an excess of myocardial infarction deaths. ${ }^{18}$ This, however, would be expected anyway as we have shown in both high risk and low risk groups a continuous positive relation between weight and packed cell volume and diastolic blood pressure. They also suggested ill health as an underlying factor because a J curve relation between diastolic blood pressure and non-cardiac deaths was noted. We could not confirm this observation in our more heterogeneous database.
We do not, however, deny that in elderly, frail subjects ill health and poor left ventricular function may be responsible for low diastolic blood pressure and an excess of coronary and non-coronary deaths.

With respect to overtreatment as a cause of the $J$ curve $^{2}$ our data clearly showed that the lower the diastolic blood pressure the lower was the frequency of antihypertensive treatment in both high risk (with $\mathrm{U}$ curve) and low risk (no U curve) groups. Moreover, the $\mathrm{U}$ curve occurred in both treated and non-treated subjects in this and other studies. ${ }^{17} 18$

As low diastolic blood pressure was associated with a poor outcome only in patients with overt coronary disease and not in those without such disease there is the possibility that the low pressure itself is not conducive to excess mortality. Rather, in the presence of diseased coronary circulation low diastolic blood pressure may be potentially lethal whether induced by treatment or not. Nevertheless, although we have taken into account the effects of the myocardial infarction-for example, by excluding subjects with congestive heart failure and including the fall in diastolic blood pressure as a result of the initial myocardial infarction - it remains possible that we are looking at a surrogate of the extent of myocardial damage induced by the myocardial infarction. Epidemiological studies such as the Framingham study cannot resolve such questions.

Our data shed no light on the actual mechanism of the $U$ curve but they are consistent with the concept that severe coronary heart disease is associated with poor coronary flow reserve. Thus patients with severe coronary heart disease may be vulnerable to low coronary perfusion pressures (diastolic blood pressure) that are well tolerated by lower risk subjects. Our data suggest that an age and sex independent $U$ curve relation exists for diastolic blood pressure and coronary heart disease deaths in patients with myocardial infarction but not in a low risk group without myocardial infarction. The relation seems to be independent of left ventricular function and antihypertensive treatment. Any prospective studies set up to test these claims should be careful to document patients in terms of ischaemic heart disease.

This study was supported by grant HL-40423 (to RBD'A) from the American Heart, Lung and Blood Institute.

1 Lew EA. High blood pressure, other risk factors and longevity: the insurance viewpoint. Am F Med 1973;55:281-94.

2 MacMahon S, Peto R, Cutler J, Collins R, Sorlie P, Neaton J, et al. Blood pressure, stroke, and coronary heart disease. Part 1 . Prolonged differences in blood pressure: prospective observational studies corrected for the regression dilution bias. Lancet 1990;335:765-74.

3 Stewart IMcDG. Relation of reduction in pressure in first myocardial infarction in patients receiving treatment for severe hypertension. Lance 1979;i:861-5.

4 Cruickshank JM. Coronary flow reserve and the J curve relation between diastolic blood pressure and myocardial infarction. BMF 1988;297:1227-30 5 Anderson TW. Re-examination of some of the Framingham blood pressure data. Lancet 1978;ii:1139-41.

6 Cruickshank JM, Thorp JM, Zacharias FJ. Benefits and potential harm of lowering high blood pressure. Lancet 1987; ;:581-4.

7 Waller PC, Isles CG, Lever AF, Murray GD, McInnes GT. Does therapeutic reduction of diastolic blood pressure cause death from coronary hear disease? F Hum Hypertens 1988;2(1):7-10.

8 Fletcher A, Beevers DG, Bulpitt CJ, Butler A, Coles EC, Hunt D, et al. The relationship between a low treated blood pressure and IHD mortality. A report from the DHSS hypertension care computing project (DHCCP). f Hum Hypertens 1988;2(1):11-5.

9 Alderman $\mathrm{MH}$, Ooi $\mathrm{WL}$, Madhavan S, Cohen $\mathrm{H}$. Treatment-induced blood pressure reduction and the risk of myocardial infarction. $\mathcal{F} A M A 1989 ; 262$ 920-4.

10 Samuelsson OG, Wilhelmsen LW, Pennert KM, Wedel H, Berglund GL. The $\mathrm{J}$-shaped relationship between coronary heart disease and achieved blood pressure level in treated hypertension: further analyses of 12 years of followup of treated hypertensives in the primary prevention trial in Gothenburg Sweden. 7 Hypertens 1990;8:547-55.

11 Stokes J, Kannel WB, Wolf PA, Cupples LA, D'Agostino RB. The relative importance of selected risk factors for various manifestations of cardio vascular disease among men and women 35 to 64 years old. 30 years of follow-up in the Framingham study. Circulation 1987;75(suppl V): V65-73. 12 Dawber TR. The Framingham study: the epidemiology of atherosclerotic disease. Cambridge, Mass: Harvard University Press, 1980.

13 Cupples LA, D'Agostino RB. Some risk factors related to the annual incidence 
of cardiovascular disease and death using pooled repeated biennial measurements. In: Framingham heart study, 30 year followup. Sect 34. Washington, DC: National Institutes of Health, 1987. (NIH 87-2703.)

14 Cupples LA, D'Agostino RB, Anderson K, Kannel WB. Comparison of baseline and repeated measure covariate techniques in the Framingham heart study. Stat Med 1988;7:205-18

15 D'Agostino RB, Lee M, Belanger AJ, Cupples LA, Anderson K, Kannel WB. Relation of pooled logistic regression to time dependent Cox regression analysis: the Framingham study. Stat Med 1990;9:1501-15.

16 MacMahon S, Peto R, Cutler J, Collins R, Sortie P, Neaton J, et al. Blood pressure, stroke, and coronary heart disease: part 1, prolonged difference in blood pressure: prospective observational studies corrected for the regression dilution bias. Lancet 1990;335:765-74.

17 Coope J. Hypertension: the cause of the J-curve. I Hum Hypertens 1990;4:1-4 18 Staessen J, Bulpitt C, Clement D, De Leeuw P, Fagard R, Fletcher A, et al. Relation between mortality and treated blood pressure in elderly patients with hypertension: report of the European Working Party on High Blood Pressure in the Elderly. BMF 1989;298:1552-6.

\title{
Measures of performance in Scottish maternity hospitals
}

\author{
A H Leyland, C W Pritchard, P McLoone, F A Boddy
}

\begin{abstract}
Objective-To develop measures of hospital performance over time with particular reference to maternal and neonatal care by controlling for case mix.

Design-Analysis of computerised records of births.

Setting-Scotland, 1980-7.

Subjects-Over half a million singleton live births and stillbirths.

Main outcome measures-Numbers of perinatal deaths and caesarean sections.

Results-Scottish maternity hospitals perform more or less equally with regard to perinatal mortality. When caesarean sections are considered, there is evidence that hospitals differ in their treatment of different groups of women; in two examples one hospital had an increased rate among women of parity $\mathbf{2}$ or more and another had a reduced rate of repeat caesarean section.

Conclusions-Developing measures of performance over time by controlling for case mix is a valid system for monitoring hospital outcomes and activity, and allows comparison either between hospitals or with data for all Scottish maternity hospitals. Hospital profiles permit identification of differences for particular patient groups after allowance is made for other case mix variables.
\end{abstract}

\section{Introduction}

In the pursuit of improved efficiency, management policies in the NHS have focused increasingly on the use of performance indicators. Most such measures are concerned with crude indicators of resource use $\mathrm{e}^{2}$ and few make allowance for the ways in which the characteristics of the patients treated in a hospital (or health authority) may influence either the use of resources or the outcomes that are achieved. It should be self evident that performance indicators are, at best, difficult to interpret if they do not take account of variation in the case mix of hospitals and thus the work they undertake.

This general point is illustrated by the example of Scottish maternity hospitals in 1980-7. For this period the perinatal mortality rate in Scotland was $9 \cdot 7 / 1000$ births; individual rates for the 46 hospitals delivering more than 800 babies ranged from less than one to more than 13 deaths per 1000 births. In the same period, the rates of caesarean section for the 30 hospitals employing this mode of delivery varied between $5 \%$ and $18 \%$ compared with a rate in all Scotland of $13 \%$. Taken at face value, these differences suggest either variations in clinical practice and in the quality of obstetric care or - the more likely explanation - that hospitals differ in the types of cases they manage. If this second interpretation is correct then it has obvious implications for interpreting resource related descriptors of hospital activity. Some of these factors are considered by Lynch in an econometric study of the variation in cost per case among 35 of the hospitals we analysed.

A major difficulty in devising and applying performance indicators is that they depend on information that is routinely available (usually for other primary purposes) and thus on the post hoc ability of this information to reflect "performance" in more complex ways than, for example, the number of patients processed in a given time interval. Most NHS information systems fail to provide sufficient detail about patients' characteristics or the content of clinical care to allow proceeding much beyond the general comparisons included in published lists of performance indicators. The system of Scottish morbidity records used for maternity and neonatal care (forms SMR2 and SMR $11^{4}$ ) is an exception for two reasons: firstly, the forms include data about the circumstances of the pregnancy and its outcome, and, secondly, they are completed for nearly all births occurring in Scottish maternity hospitals. It is thus possible to compare hospitals in terms of differences in their case mix and to make allowance for these differences when interpreting the outcomes the hospitals achieve or the activities they undertake.

\section{Methods}

The analysis used data for singleton births from routinely completed maternal and neonatal discharge records (forms SMR2 and SMR11) for births in Scotland during 1980-7. The forms provide information about the mother (demographic and obstetric characteristics) as well as details of the recorded pregnancy. The records included $98 \%$ of all pregnancies in Scotland; 514193 records from 96 hospitals were included in the analysis. The reporting of deaths was slightly less complete, consisting of $98 \%$ of stillbirths, $97 \%$ of early neonatal deaths, and $93 \%$ of late neonatal deaths (S K Cole, personal communication). In all $8.8 \%$ of all live births were transferred from the hospital of birth to another hospital; these accounted for $12.6 \%$ of all deaths in the first week. All such transfers were ascribed to the birth unit. No systematic bias was found in either the reporting of deaths or the distinction between deaths in the first week and early neonatal deaths between hospitals or hospital types.

The data were formed into a multidimensional contingency table and a logistic regression ${ }^{56}$ was performed for each outcome measure by using GLIM $3.77^{7}$ with each of the 14 variables listed in the table regarded as a factor with two to eight levels. These variables were chosen as classic explanatory variables from previous studies ${ }^{8-10}$ under the constraint of the availability of the data. The purpose of this initial model fitting was to define a statistical model for selected outcomes (numbers of perinatal deaths and caesarean sections) that would account for variations in the data for all years included in the study. Only
Leyland.

BMF 1991;303:389-93 